trana conference

Art, Illustration and Visual Culture

in Infant and Primary Education

\title{
Considering the Drawing Education for Children during the 19th Century to the 2oth Century in England
}

Mariko Kaname mariko@cscd.osaka-u.ac.jp Osaka University, Japan

Reference

Kaname, Mariko; (2012) "Considering the Drawing Education for Children during the 19th Century to the 2oth Century in England", p. 153-157. In: Barbosa, Helena; Quental, Joana [Eds]. Proceedings of the 2nd International Conference of Art, Illustration and Visual Culture in Infant and Primary Education. São Paulo: Blucher, 2015 ISSN 2318-695X, ISBN: 978-989-98185-0-7

DOI 10.5151/edupro-aivcipe-30

This paper is an attempt to trace the development of the drawing education of children during the early 19th century to the early 2oth century in England on a theoretical basis and to investigate it aesthetically, checking this development against the current shift of the Western conception of nature. In education philosophy after Rousseau, it is important to retain "naturalness"; great sensibility, imagination, and innocence, in children. On the other hand, in England, an educational role was thought to humanize this naturalness, to make it into that which contributed to the existing society. In this paper, I will trace the modern history of English art education, comparing it with an understanding of drawings by children under the word of "primitive" and will clarify the turning point of negative meanings to positive ones.

Keywords Nature, primitive, modern art, drawings by children, creativity

\section{Introduction}

\section{The discovery of childhood and education for children}

It is considered that modern child educational theories in Europe have originated from Genevan philosopher Jean-Jacques Rousseau (1712-1778). His way of thought expressed the property of taming nature, children and their sensibility, and creativity. Actually, he wrote in the beginning of his Emile Book 1, "God makes all things good; man meddles with them and they become evil," and he emphasized the necessity of an educational method for a child's image of nature, which differs compared to adults, thinking of children as nature because of their innocence (Rousseau/Foxley, 1911/1957: 5). His educational philosophy of treating children the same as nature was continued by the pioneers of child education in Europe, such as Johann Heinrich Pestalozzi (1746-1827) and Friedrich Fröbel (1782-1852). Especially in art education, the necessity of a system that cultivated a child's innate naturalness and that included exercise for adapting naturalness to human society was coming to be recognized. This differed substantially from traditional educational systems, such as apprenticeships for vocational training or professional education at art academies. In this presentation, I will provide an overview of the child art education that caused Rousseau's idealistic naturalism to be modified and accepted in modern England from the late 19th century to the early zoth century, comparing it with an understanding of drawings by children under the word of "primitive," while clarifying the turning point of negative meanings to positive ones.

It is said that the tendency to find and praise the great sensibility, imagination, and innocence of children, considered as "small adults" in pre-modern times, originated in Jean-Jacques Rousseau. This idea has had impact on art education until now. In fact, Rousseau thought that children should learn from nature without imitating the art of adults. 
I shall take good care not to provide him with a drawing master, who would only set him to copies and draw from drawings. Nature should be his only teacher, and things his only models. He should have the real thing before his eyes, not its copy on paper. Let him draw a house from a house, a tree from a tree, a man from a man; so that he may train himself to observe objects and their appearance accurately and not to take false and conventional copies for truth. (Rouseau/Foxley, 1762/1957: 108)

His purpose was to not equip good taste and technical capacity enabling children to draw "a graceful outline" or the "light touch of the draftsman," nor to appreciate a "picturesque effect." It is more important that children learn from immediate experiences through the use of their senses. Therefore, this type of education was isolated from traditional classicist education for academic artists as well as for technical training for workers.

His educational philosophy that focused on immediate experiences was systematized by a Swiss educational reformer, Pestalozzi, under "object lesson Sachunterricht" through intuition. However, it should be noted that his attention is on the training of grasping the concepts to "live" rather than the cultivation of sensibility or expressiveness. He thought that there must be a special way of education commensurate with a child's character and development. He also suggested that "lines, angles, and curves are the foundation of the art of drawing" (Pestalozzi, 1801/1898: 116-119), and that the drawing method was proceeding from the simple and intuitive, to the more complicated and difficult forms; from "the form of geometric exercises and observation practice onto man-made forms, then onto natural forms such as plants and animals, concluding with the human form" (quoted in Ashwin, 1981: 56).

Pestalozzi's educational method using intuition that was inherited from Rousseau's idea developed into two directions for child education later on. One is German-Romantic aesthetic education, such as Goethe and Schiller, which aimed at nurturing the innate nature of children. It was thought that a child's creativity connected with divinity. Another is the utilitarian art education that was imported in the early 19th Century to England. For the enhanced convenience of general workers, the exercise of the mechanical copy of outlines was adapted into the elementary school curriculum. Then, there was also the acquisition of the technical ability required, which Rousseau and Pestalozzi had left aside.

On the one hand there was aesthetic and ethical education, while on the other hand there was mechanical technical training, and this was how drawing education for children was addressed. As for both artwork and industrial products, ideal form was thought of as a complete work that adults created. Eventually, children were led to aspire toward the work of adults, though doing such required a different training process for children and adults. Therefore, it took a long time for drawings by children to become recognized as artistic expression and for carrying out such education for such expression.

\section{The unique nature of} children and "primitive"

Since "the discovery of childhood" in the 18th century, it has been disputed how to properly adjust a child's nature into human society regarding education. Even in the later 19th century, voluntary artistic creativity was not found in drawings by children unless it was deemed that they were taught by teachers or the "Gods."

As a typical example of educational ideas at the time, Children's art: (L'arte dei babini in 1887), written by Italian art historian Corrado Ricci (1857-1934), should be mentioned. He discovered "childness" in graffiti on a wall. However, this "childness" was not appreciated as artistic nature, but recognized as nature in a stage prior to art. The nature of "childness" was placed in the early stage of human development, and was even as widespread as Herbert Spencer's Darwinism and Ernst Haeckel's Recapitulation Theory, which arose in the 19th century. Especially, Haeckel's theory that claims that the development of every individual organism recapitulates the entire evolutionary development of the species as well as that the mental development of an infant recapitulates the evolutionary development of the human mind became widely understood among educators through psychology.

English psychologist, James Sully (1842-1923) stated, "As we all know, the lowest races of mankind stand in close proximity to the animal world. The same is true of the infants of civilized races." (Sully, 1895/1896: 4) As mentioned, for "the lowest" here, above all in sociology, an 
2nd International Conference Art, Illustration and Visual Culture in Infant and Primary Education $2^{\circ}$ Congreso Internacional

Arte, llustración y Cultura Visual en Educación Infantil y Primaria
Figures 1 and 2. On the left: drawing by a Native American, on the right: drawing by a child illustrated by James Sully in Studies of Childhood (1895/1896: 379, 381) extended interpretation that primitive tribes placed in the low stage of evolution would be suggested.

The conclusion which observation of children leads us to is that, as compared with adults, they are endowed with strong imaginative power, the activity of which leads to a surprisingly intense inner realisation of what lies above sense. For the child, as for primitive man, reality is a projection of fancy as well as an assurance of sense... Savages, who show so striking a resemblance to children in the vivacity and the dominance of their fancy, are probably much nearer to the child than to the civilised adult in the condition of their brain. (Sully, 1895/1896: 62).

"Imaginative power" and "vivacity," used as positive comments nowadays, could not be factors in artistic expression. On the contrary, Sully compared the cognitive process to expression in his analysis, rather than the means of expression itself. In particular, he wanted to say that drawings by children as well as those by primitive man were made on the basis of the grasping of concepts, rather than of a direct copy of visual perception. In the case of drawing a person on a horse, a child tries to describe the person's legs, which he or she could not see on the opposite side of the horse's body (Fig. 1.2).

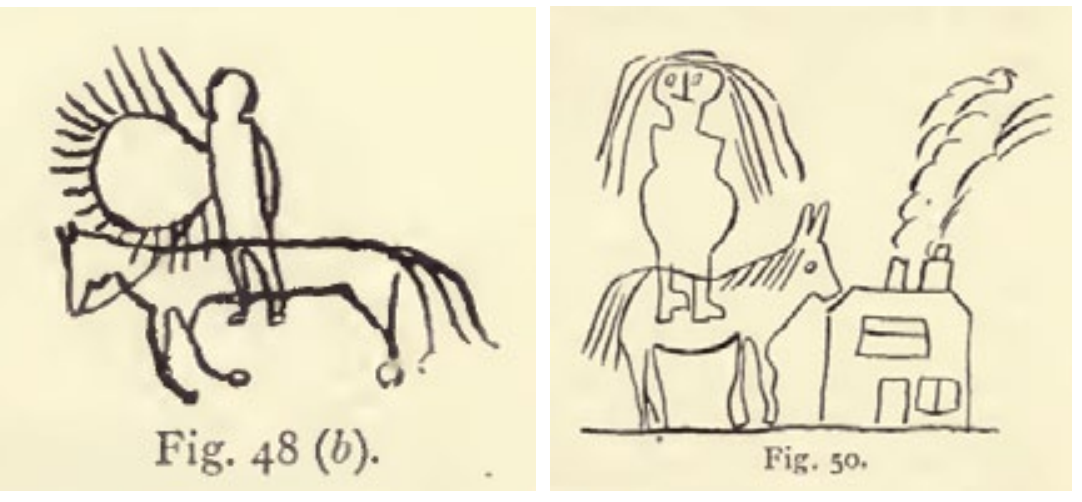

Hence when he [5 or 6 year old children] comes to draw he has not the artist's clear mental vision of the actual look of things to guide him. He is led not by a lively and clear sensuous imagination, but by a mass of generalised knowledge embodied in words, viz., the logical form of a definition or description. (Sully, 1895/1896: 395).

The common nature among childhood, the earlier stage in human history, along with that of the "savages," came to be called the "primitive." As written in Sully's book, a child's work was thought as primitive in the art theory of those days.

\section{Drawings by children as artistic expression}

Indeed, it was demonstrated scientifically by James Sully that drawings by children are an expression of grasping concepts and that anyone can fail to make proper evaluation using the traditional standard "imitation of nature." However, even if the cognitive process of children was revealed through the drawing process, drawings by children receive a low rating unless they are acknowledged as artistic expression. The problem is about when and how to shift the value of a child's drawing from negative to positive.

During the early years of the zoth century, a new kind of artistic style rapidly appeared that could not be judged using the standard of the "imitation of nature." Some of this art represented not an object of nature, but rather an image dissimilar to the original motif and model. An English art critic Roger Fry (1866-1934), who organized post-impressionist shows in 1910 and 1912, found this expression known as "primitive" to be independent of the "imitation of nature" in ethnic art and drawings by children. He appreciated both modern art and drawings by children from the viewpoint of art form. In his early essay, Expression and Representation in the Graphic Arts (1908), he already criticized academic art, which dominated the art world, "we find that no test of accuracy in the imitation of the appearances of nature will ever suffice to distinguish between what we find to be great works of art and inferior ones." (Fry, 1908/1996: 63) He judged some works of modern academic painters such as Edward Poynter or Laurence 
$2^{\text {nd }}$ International Conference Art, Illustration and Visual Culture in Infant and Primary Education $2^{\circ}$ Congreso Internacional

Arte, llustración y Cultura Visual en Educación Infantil y Primaria
Congresso Internacional

de Arte, llustração e Cultura Visual

na Educação Infantil e Primária

Alma-Tadema as "the deplorable level of stereotyped sentimentality," comparing these with post-impressionist art (Fry, 1926/1956: 35). It is important for him the way the constituents are put together in a certain artwork, which is the relationship between visual elements; lines, forms, color, and so on. These types of paintings would be appealing to people directly, beyond differences of time and culture more than the descriptive paintings regarding subject matter. It may be that post-impressionists are not completely dedicated in feeling, but rather he attempts to organize the components into an artistic form.

Meanwhile, championing post-impressionists against academic and impressionist art, he stressed the role of understanding the process of drawings. This involves imaginative power that recreates the form. Then, a "thing" perceived by the eyes is simplified and colored by one's conceptual habits. Fry called such emphasis and distortion as the "concept-symbol" found in both primitive and child drawings, associating them with individual expressiveness. "Primitive art, like the art of children, consists not so much in an attempt to represent what the eye perceives, as to put a line around a mental conception of the object. Like the work of the primitive artists, the pictures children draw are often extraordinarily expressive" (Fry, 1910/1996: 84).

As seen above, Fry was interested in "child art" with a theoretical motive. He planned exhibitions of drawings by children in 1917, 1924, and 1933, commenting on the drawings regarding the viewpoint of the unity of form that was attained in the "concept-symbol" process. In the exhibition of 1924, he reviewed several drawings. For example, this is The Boxing Match (Fig. 3), drawn by a 12-year-old girl, Winifred Edwards. It was not sketched there and then. "The motive of this was a paragraph in a newspaper describing a prize-fight in a modern amphitheatre." She tried to "express all the successive mental images that the description evoked" (Fry, 1924: 41). There are many spectators in the venue; we can see the columns supporting the tier and two groups of spectators sitting underneath; the grand tiers represented by the two curves at the top of the picture. It is possible to find the curious blending of a diagrammatic method with the partial application of perspective in the spatial relation between the central electric light and the tier. "A method not unlike that of some early oriental artists. Like them, too, our child artist has organized this curiously mixed vision into something that at least has a strongly marked formal unity though only of a decorative nature" (Fry, 1924: 41).

Figure 3. On the left: Drawing by Winifred Edwards (aged 12), The Boxing Match, watercolor illustrated by Roger Fry in "Children's Drawings" (1924: 37)

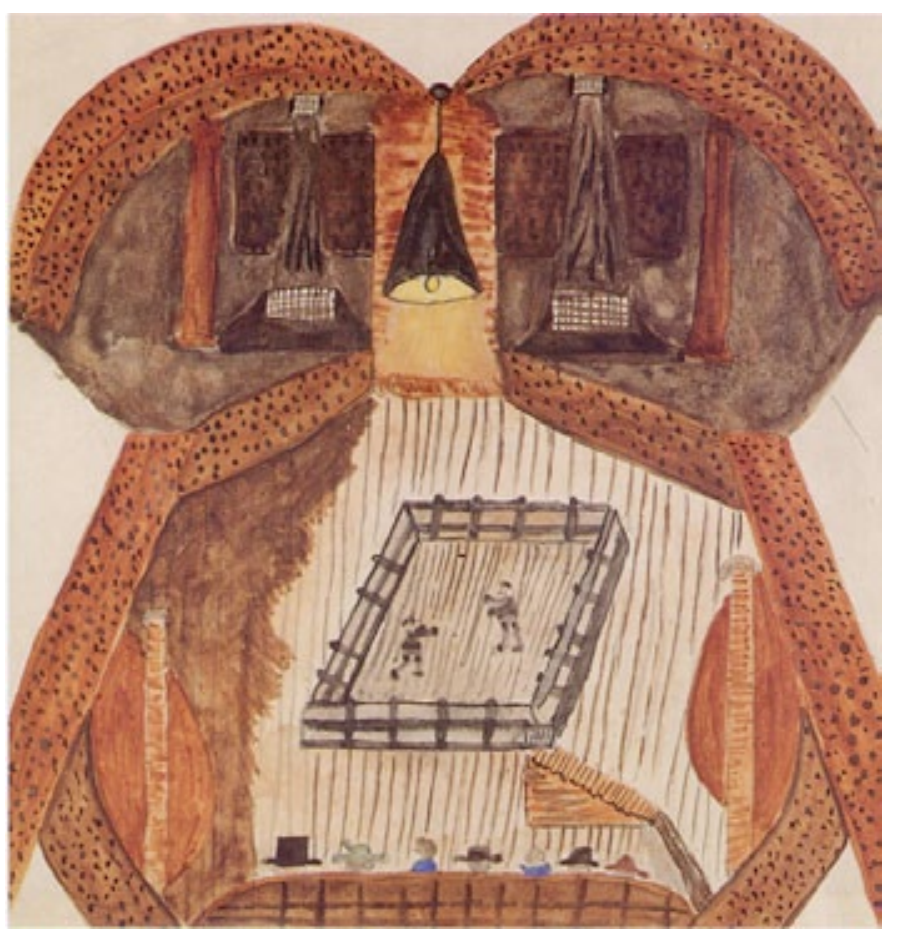


$2^{\text {nd }}$ International Conference Art, Illustration and Visual Culture in Infant and Primary Education
${ }^{\circ}$ Congresso Internacional

de Arte, Ilustração e Cultura Visual

na Educação Infantil e Primária

He pointed out that children could find the existing rules in their own experience by chance, even if they would not be learned from someone else. This statement reminds us of Rousseau's idea.

When a young English art lecturer, Marion Richardson (1892-1946), visited the exhibitions, Fry's idea such that there is analogy between modern art and drawings by children led to contact with art education. Richardson also conducted art classes by using a method that focused on the original ideas and creativity of children, questioning traditional school education that let pupils repeat imitation after academic method. If one of her methods were to be shown here, the "writing pattern" must be an appropriate example. She thought that "pattern," as the concept of a formal principle of composition, along with the feeling of unity, was the most important criterion for art.

Now Miss Richardson has discovered a way to give satisfaction to this overpowering desire of infancy for colour. The children are all more or less familiar with some written letters, they can at least make the preliminary pot-hooks and so she gets them to make patterns by using these simple and easily made forms in different combinations and then filling in the spaces with colour. (Fry, 1933: 844).

Blending her educational method with Fry's theory, after his death, with the support of Herbert Read (1893-1968), educational ideas regarding art that emphasize a children's primitive creativity became mainstream in child art education in the later 2oth century. In this process, it is the emphasis on child creativity that altered Fry's idea of the intellectual form based on concept to Read's idea of the restoration of a child's first unitary perceptions.

\section{Conclusion}

Even child education for drawings came to be recognized as self-expression as a substitute for self-activity that depended on the imitation of nature in the 19th century. "Childness" has been estimated as low, equivalent to untouched nature. At the end of the 19th century to the early 2oth century, James Sully discovered the recognition process of children in their drawings, and Roger Fry accepted the artistic expressiveness in them. The turning point of the significance of "childness" arose at the same time as the discovery of primitive art and the appearance of modern art. Then, the meaning of "childness" as well as "primitive" changed from "savageness" or "rudeness" into "expressiveness." Nowadays, the educational philosophy of child art shifted from training in the imitation of nature based on the standard of academic art into educating the individual expressiveness of children. Ironically, I think adults today have come to construe these unconventional expressions as including "childness" as a new "standard," especially regarding child art.

\section{Bibliographical references}

Ashwin, C. (1981). Drawing and Education in German-speaking Europe: 1800-1900. Ann Arbor, MI: UMI Research Press.

Fry, R. (1908). "Expression and Representation in the Graphic Arts." A Roger Fry Reader. Chicago: The University of Chicago Press (1996), pp. 61-71.

Fry, R. (1924). "Children's Drawings." Burlington Magazine, Vol. 44, January, pp. 35-41.

Fry, R. (1926). "Some Questions in Esthetics." Transformations, New York: Doubleday \& Company (1956), pp. 89-108.

Fry, R. (1933). "Children's Drawings." New Statesman and Nation, June 24, pp. 844-45.

Pestalozzi, J. H. (1801). How Gertrude teaches her children. Trans. by L. Holland \& F. Turner. Syracuse: C. W. Bardeen (1898).

Rousseau, J. J. (1761). Emile. Trans. by Barbara Foxley. London: J. M. Dent \& Sons (1957).

Sully, J. (1895). Studies of Childhood. New York: D. Appleton \& Company (1896). 